\title{
CORRESPONDENCE
}

\section{Growth Hormone Testing and the Short Child}

To The Editor: Thank you for asking me to comment on the Letter to the Editor provided by Dr. Mauras in response to my commentary on the article published in Pediatric Research $(1,2)$. Based upon this report, Dr. Mauras contends that serum growth factor determinations of IGF-I, IGFBP-3, and ALS may be more sensitive indicators of "GH sufficiency" than stimulated GH concentrations. To respond adequately, I must add the following points to my prior commentary. To support this claim, the authors must delineate which of the short stature group were accurately diagnosed with GH deficiency (not sufficiency), and hence what the clinical utility of these measurements actually is compared with $\mathrm{GH}$ testing in this population. Although the severely short child with a height SDS of -7.4 has now been excluded from the comparative analysis of GH-dependent growth factors, we are not informed what diagnosis this child actually has, and whether he had a normal MRI examination. The authors should also respond to other published work that does not support this claim $(3,4)$.
Furthermore, there are concerns with the entire short stature cohort. They were significantly younger by almost $2 \mathrm{y}$ than the control group, and we are told that growth velocity was not available in eight subjects. At least one subject was not even short (HT SDS $=+0.7)$. These children would not have been studied if we followed the authors' own recommendations: "GH stimulation tests should be reserved for those with low circulating growth factors and poor growth" (p. 618). As well as being younger, the short stature group was also very different in pubertal status ( $21 \%$ in puberty versus $46 \%$ in the control group). Since puberty is known to be associated with increased serum IGF-I concentrations, mean differences, even with the exclusion of children under age $6 \mathrm{y}$, would be expected. The correction by SDS does not appear to completely remove this confounding factor, since at least one normal subject was in advanced puberty with an IGF-I of +4.0 SDS.

In closing, the authors have reported an important study that highlights the need to adjust cut-off levels for GH stimulation tests based upon current assay technology. There are no objective data in this report upon which to support a claim that serum growth factor determinations are superior to $\mathrm{GH}$ stimulation tests in the identification of children with GH-deficiency, especially if more potent GH stimulation tests are selected, as they also suggest.

Harvey Guyda Montréal Children's Hospital 2300 Tupper Street Montreal, Québec H3H 1P3 Canada

\section{REFERENCES}

1. Mauras N, Walton P, Nicar M, Welch S, Rogol AD 2000 Growth hormone stimulation in both short and normal statured children: use of an immunofunctional assay. Pediatr Res 48:614-618

2. Guyda HJ 2000 Growth hormone testing and the short child. [commentary] Pediatr Res 48:579-580

3. Tillman V, Buckler JMH, Kibirige MS, Price DA, Shalet SM, Wales JKH, Addison MG, Gill MS, Whatmore AJ, Clayton PE 1997 Biochemical tests in the diagnosis of childhood growth hormone deficiency. J Clin Endocrinol Metab 82:531-535

4. Mitchell MH, Dattani MT, Nanduri V, Hindmarsh PC, Preece MA, Brook CG 1999 Failure of IGF-I and IGFBP-3 to diagnose growth hormone deficiency. Arch Dis Child 80:443-447 